Understanding Global Slavery 
The publisher gratefully acknowledges the generous contribution to this book provided by Sally Lilienthal. 


\section{Understanding Global Slavery}

A Reader

Kevin Bales

UNIVERSITY OF CALIFORNIA PRESS

Berkeley / Los Angeles / London 
University of California Press

Berkeley and Los Angeles, California

University of California Press, Ltd.

London, England

(C) 2005 by The Regents of the University of California

Library of Congress Cataloging-in-Publication Data Bales, Kevin.

Understanding global slavery : a reader / Kevin Bales.

p. $\mathrm{cm}$.

Includes bibliographical references and index.

ISBN 0-520-24506-7 (cloth : alk. paper) - ISBN 0-520-24507-5 (pbk. : alk. paper)

I. Slavery. 2. Slave labor. 3. Forced labor. 4. Prostitution. 5. Slave trade. I. Title.

HT867.B38 2005

$306.3^{\prime} 62-\mathrm{dc} 22$

2005002967

Manufactured in the United States of America

$\begin{array}{llllllllll}\text { I4 } & \text { I3 } & \text { I2 } & \text { II } & \text { IO } & 09 & 08 & 07 & 06 & 05\end{array}$

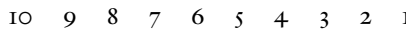

The paper used in this publication meets the minimum requirements of ANSI/NISO Z39.48-I992 (R 1997) (Permanence of Paper). 
To Larry DeBord 
